\title{
The Status and Significance of Innovation and Entrepreneurship Education in Colleges and Universities
}

\author{
Fengyun Yao \\ Guangdong Nanfang Vocational College \\ Jiangmen, Guangdong, 529000, China \\ Email: yaofengyun1025@163.com
}

\begin{abstract}
This article first illustrates the connotation of innovation and entrepreneurship education, then points out the status of innovation and entrepreneurship education in colleges, and finally analyzes the significance of innovation and entrepreneurship education. The article suggests college leaders, educators, and administrator should clear the orientation and significance of innovative entrepreneurial education, pay more attention to the innovation entrepreneurship education in colleges and universities, and then effectively implementing innovation and entrepreneurship education, with improving the level of their education constantly.
\end{abstract}

Keywords: colleges and universities; innovation entrepreneurship education; status; significance.

\section{INTRODUCTION}

On December 14, 2015, the ministry of education issued "Notice on the employment and entrepreneurship work of 2016 graduates of national ordinary colleges and universities" stressed that since 2016, all colleges and universities should set up the innovative entrepreneurship education course, open to all students develop innovation entrepreneurship education compulsory courses and elective courses, incorporated into the credit management. As being knowledge innovation, dissemination, application and training of high-level personnel of the institutions of colleges and universities, to implement the national policy, strategic thinking, and the education policy, should pay more attention to education of innovative entrepreneurial management personnel training. This article discusses the issue of "positioning and significance of education in university innovation and entrepreneurship".

\section{THE CONNOTATION OF INNOVATION AND ENTREPRENEURSHIP EDUCATION}

\section{A. Innovation Education Concept}

The term "innovation", "the modern Chinese dictionary" interprets it as "create new" to abandon the old, also explain "creative, innovative", and "innovation" can be described as in new thinking, new inventions and new described as a conceptual process characteristics. However the concept of "education innovation" is controversial in the academic world. Actually it can be considered as the innovation education is different from accepting education, conformity education or traditional education of a new type of education mode, its core idea is to cultivate students' innovation spirit and innovation ability, innovation quality.

\section{B. Entrepreneurship Education Concept}

The term "entrepreneurship", which "the modern Chinese dictionary" defines as "entrepreneurship", is a dynamic process. Compared with innovation education, "entrepreneurial education" has been universally recognized in the theoretical field. Education in human society has experienced the two stages of education and education respectively. For a long time, Shouye education refers to the education activity guided by the closed thought of maintaining the old industry and being confined to the status quo, with the aim of maintaining tradition and maintaining the normal state. Education refers to the education reform of making full use of students' entrepreneurial potential, exploring students' entrepreneurial potential, improving students entrepreneurial ability and cultivating first-class entrepreneurs. In fact, it can be considered that entrepreneurship education is the education that helps students prepare for the early stage of theory and practice, and sets up the concept of entrepreneurship, and cultivates of entrepreneurial ability.

Entrepreneurship education is 1989 UNESCO in discussion Facing the development trend of international education in the 21 st century At that time A new concept of education was proposed. Also known as the "third educational pass", it is to prove one's ambition and pioneering ability. It is of equal importance to academic education and professional education.

Entrepreneurship education is a new concept of education presented by UNESCO in 1989 for discussion when facing the $21 \mathrm{st}$ century international education development trend puts, also known as the "third educational pass", which proves one's ambition and pioneering ability. Entrepreneurship education is of equal importance to academic education, and vocational education.

\section{The Relationship between the Innovative Education and Entrepreneurial Education.}

The meaning of innovation is to establish a kind of new way of thinking. Entrepreneurship represents a new career, entrepreneurial innovation spirit and innovation ability, innovation directly influences the degree of entrepreneurial success or failure, is closely related between the innovative education and entrepreneurial education. Entrepreneurial education can only develop on 
the basis of innovative education, and innovative education needs to achieve education goals through entrepreneurial education.

\section{UNIVERSITIES AND COLLEGES INNOVATION AND ENTREPRENEURSHIP EDUCATION STATUS}

The vice chairman of China invention association professor Zhang Kaixun considers education should have three levels: first level is: educatees should have been made aware of the world, becoming a man of knowledge and objective; The second level is: the educatees should know why the world is like this, becoming a thinking, rational and analytical person; The third level is that the educatees should know how to make the world a better place and be brave enough to explore. Because only exploration can add new knowledge to mankind, and creation can bring new happiness and beauty to the world. Creation is the highest and ultimate goal of education.

"Colleges and universities in the United States should equip students with vital creative knowledge and skills," said by Harvard University President Mr.Pucci. In his opinion, this talent is the dividing line between top talents and third-rate talents. For this reason, as early as the 1950s, Harvard University listed creation as one of the basic subjects of students. America's middle and primary schools not only demands students to master the teacher imparting knowledge, but also pay more attention to cultivate the students' learning ability, practical ability, problem solving and independent thinking ability, and let them maximize their imagination and creativity.

In 1996, the report of "Learning: the treasure within" by International education committee for the 21 st century stressed that: "the task of education without exception to all creative ability and creative potential bear rich fruit. This goal is more important than any other."

Abovementioned discuss by Prof.Zhang Kaixun and President Pucci, the development of creativity and training creative talents, namely innovative entrepreneurial talent, is the highest level of contemporary education and the purpose of the most fundamental and most important task, and bear the mission of education, creative education should be strengthened, in order to embody the creative education in the higher position in the contemporary education.

\section{THE SIGNIFICANCE OF INNOVATION AND ENTREPRENEURSHIP EDUCATION}

A. Colleges and Universities Innovation Entrepreneurship Education is the Need to Build an Innovative Country and Implement Innovation-driven Development Strategy

The 17th national congress of the communist party of China (CPC) put forward a new development idea of "improving the capability of independent innovation and building an innovative country". The 18th CPC national congress also proposed the "innovation-driven development strategy". The nineteenth congress of the party put forward "Accelerating the building of an innovation-oriented country" Slogan. The primary task of building an innovative country and implementing an innovation-driven development strategy is to cultivate the spirit of innovation in the whole society. To a large extent, the cultivation of innovation spirit and innovative talents depends on innovation and entrepreneurship education. This puts forward the urgent requirement for the cultivation of innovative talents in colleges and universities. Therefore, education has a special mission to cultivate innovative talents.

If our Country each year has millions of college graduates generally develop certain innovation ability, some of them would become innovation entrepreneurship talents with high level, which can play a good role in the "public entrepreneurship, peoples innovation", then, the innovative entrepreneurial human resources advantage can be reflected. There is no comparison between material wealth and spiritual wealth creation in China. Our economy can take off more quickly. Therefore, colleges and universities innovation entrepreneurship education is the need to build an innovative country and implement innovation-driven development strategy.

B. Colleges and Universities Innovation and Entrepreneurship Education is the Need to Adapt to the Future Intelligence Era and Promote the Rapid Development of China's Economy

After entering the 21 st century, science and technology are changing with each passing day. Thereby, the coming age is towards a more comprehensive intellectual age. The future of talent will be in addition to have ability to implement wealth, more need to have strong ability to create material wealth and spiritual wealth.

China's institutions of higher learning are important carrier for cultivating innovative talents in the future, which needs to instructed innovation entrepreneurship theory and practice of knowledge to every college students, inspiring and promoting the formation of its innovation ability, to meet the needs of the future intelligence era. As college students, in addition, though accepted entrepreneurship education innovation, to develop innovative entrepreneurial base and internal conditions, which can have very good lead in the national innovation entrepreneurship and leadership, and add new vitality for the rapid development of economy in our Country. Therefore, colleges and universities innovation and entrepreneurship education is the need to adapt to the future intelligence era and promote the rapid development of China's economy.

\section{Colleges and Universities Innovation and Entrepreneurship Education is the Need to the State Create Employment Opportunities and Promote College Students to Realize Employment}

In recent years, the employment situation of college graduates is grim, and the contradiction between the growth rate of graduates and the insufficient effective demand is prominent. In the face of the grim employment situation and the huge employment pressure, college students innovation and entrepreneurship education must be strengthened to update the employment of college students thought, change the concept of college students' 
employment, open up various channels of employment, encourage and actively support college students to start self-employment, to make college students from a mere employed to the job creators. As entrepreneurship itself is employment, it is a high-level stage of employment. Entrepreneurship is a kind of creative labor. The key to success lies in being able to innovate. To develop entrepreneurship education is to make the students have a more comprehensive understanding of the role and value of innovative undertaking and broaden the employment view, to establish multivariate business greatly, gradually with the quality, to develop new business knowledge and ability, and change passive to active employment entrepreneurship. Therefore, colleges and universities innovation and entrepreneurship education is the need of the state to create employment opportunities and promote the employment of college students.

\section{V.CONCLUSION}

In conclusion, the status and significance of education is of great importance. Leaders, educators and administrators of colleges and universities should attach great importance to this issue. Further implementing innovation and entrepreneurship education effectively, and continuously improving its education level. More and more innovative and entrepreneurial talents have been cultivated in colleges and universities.

\section{REFERENCES}

[1] Yao Fengyun etc.. Innovation and entrepreneurial management. Tsinghua university press. Beijing. 2017.11.

[2] liu. for University student innovation and entrepreneurship education with practice the A few thoughts. China's education The newspaper. Beijing. 2016.10.13.

[3] Li renjie, shang wan jun. parsing University student Innovation and entrepreneurship education the connotation of the And meaning. Science and technology innovation guide. Beijing. 2010. 9. 